\begin{tabular}{ll}
\hline ISSN: 1410-8917 & Jurnal Kimia Sains dan Aplikasi 23 (9) (2020):312-318 \\
Jurnal Kimia & Jurnal Kimia Sains dan Aplikasi \\
Aplikasi & Journal of Scientific and Applied Chemistry \\
\hline
\end{tabular}

\title{
The Combination of Carbon Source and the Addition of Phenylacetic Acid (PAA) to Growth Medium Penicillium chrysogenum to Enhance of Penicillin (Pen G) Production
}

\author{
Martha Sari ${ }^{\text {a, }}{ }^{,}$, Dirayanti ${ }^{b}$, Eris Septiana ${ }^{a}$, Bustanussalam ${ }^{a}$, Apon Zaenal Mustopa ${ }^{\text {a }}$ \\ a Biotechnology Research Center, Indonesian Institute of Sciences, Bogor, Indonesia \\ ${ }^{\mathrm{b}}$ Chemistry Department, Faculty of Mathematics and Natural Sciences, Hasanuddin University, Makassar, Indonesia \\ * Corresponding author: martha.biotek@gmail.com
}

https://doi.org/10.14710/jksa.23.9.312-318

\begin{tabular}{l} 
Article Info \\
\hline Article history: \\
Received: $27^{\text {th }}$ April 2020 \\
Revised: $8^{\text {th }}$ August 2020 \\
Accepted: $25^{\text {th }}$ August 2020 \\
Online: $30^{\text {th }}$ September 2020 \\
\hline
\end{tabular}

Keywords:

Carbon source; PAA; $P$. chrysogenum; Pen G; Disk diffusion

\begin{abstract}
The nutrition factor governs the growth and production of Penicillin G (Pen G) by Penicillium chrysogenum in a broth medium. Proper nutrition can improve Pen G antibiotic production. In this research, the optimal condition for Pen $\mathrm{G}$ production from $P$. chrysogenum in a standard culture medium and various carbon sources medium (glucose, lactose, maltose, and sucrose) were done for ten days. Phenylacetic Acid (PAA) precursor at $0.0-0.6 \mathrm{gL}^{-1}$ (increment 0.1) was used to improve Pen G production. The Pen G was detected by HPLC, compared with the standard (Penicillin G Sodium Salt). The results showed that the PDB standard medium and lactose medium $\left(150 \mathrm{rpm}\right.$, at $30^{\circ} \mathrm{C}$ ) produced $0.425 \mathrm{gL}^{-1}$ and $0.107 \mathrm{gL}^{-}$ ${ }^{1}$ Pen G. Addition of $0.6 \mathrm{gL}^{-1}$ PAA improved the Pen $\mathrm{G}$ production up to $0.045 \mathrm{gL}^{-1}$ in the PDB medium, become the final concentration of $0.470 \mathrm{gL}^{-1}$ and $2.460 \mathrm{gL}^{-1}$ in the lactose medium, become the final concentration of $2.565 \mathrm{gL}^{-1}$. The antibiotic's activity against the pathogenic bacteria, i.e., B. subtilis, S. aureus, and S. typhi employing the disk diffusion method, has been done. The TLC method's detection of the potential Pen $\mathrm{G}$ spots was conducted with ethyl acetate: distilled water: acetic acid (60:20:20) as the mobile phase. The Pen G extracts could inhibit the growth of all tested bacteria in Rf 0.65 . This study informs the proper combination of carbon source and precursor effects and increases the bioproduction of Pen $\mathrm{G}$ from P. chrysogenum.
\end{abstract}

\section{Introduction}

Microorganism has a flexible metabolic system, especially their adaptation to chemical compounds' synthesis. The growth of microorganisms in an unfavorable (stressful) condition is frequently used to induce the production of metabolites that are more potential such as enzymes, growth factors, hormones, or antibiotics [1]. The relationship between microbes in a stressful environment contributes to selecting biotechnology products, one of which is antibiotics [2, 3]. Biotechnology products' application plays an essential role in humans and other animals and agricultural products [4]. Biotechnology products from fungi or bacteria can produce effective antibacterial compounds, e.g., penicillin $[5,6]$. Antibiotics produced and used widely in the world are the $\beta$-lactam group, some of which are penicillin, amoxicillin, and cephalosporin, which account for $40 \%$ of the antibiotic market [7, 8]. To date, the local industry is still troubled to meet the demand for $\beta$-lactam antibiotics, one of which is penicillin [9]. Antibiotics derived from penicillin have a high commercial value and acts as the basis for semisynthetic antibiotics production, e.g., Amoxicillin and Ampicillin [10]. Amoxicillin is an antibiotic derived from penicillin that is most widely used in Indonesia [11]. Penicillin's activities are effective against both Grampositive and Gram-negative bacteria [12]. The essential ingredient of a penicillin antibiotic is Penicillin $\mathrm{G}$ (Figure 1). In the fungi cells, penicillin $G$ biosynthesis involves three primary genes, namely $d(\mathrm{~L}-\mathrm{a}-\mathrm{Aminoadipyl})-\mathrm{L}-$ Cysteinyl-D-Valine Synthetase (acvA), Isopenicillin $\mathrm{N}$ Synthase (ipnA), and Acyl Coenzyme A: Isopenicillin $\mathrm{N}$ 
Acyltransferase (aatA) [13]. The biosynthesis of penicillin $\mathrm{G}$ from $P$. chrysogenum is controlled by various growth factors, including carbon source, $\mathrm{pH}$, agitation speed, duration of incubation, and types of precursors [7, 14, 15]. An essential factor in increasing the metabolism and growth of fungi in a culture is the nutrition supply. The dominant portion of the nutrition source is carbon. A study from Asnaashari et al. [14] proved the optimum Pen $\mathrm{G}$ production from $P$. chrysogenum could be done for eight days of incubation with $0.3 \mathrm{gL}^{-1}$ yeast extract and $21 \mathrm{gL}^{-1}$ glucose substrates at $28^{\circ} \mathrm{C}$ and $120 \mathrm{rpm}$ of agitation.<smiles>CC1(C)SC2C(NC(=O)Cc3ccccc3)C(=O)N2C1C(=O)O</smiles>

Figure 1. Structure molecule of Pen G [16]

In contrast, based on a study done by OnyegemeOkerenta et al. [15], $5.32 \pm 0.05 \mathrm{gL}^{-1}$ of Pen G from $P$. chrysogenum is obtained at room temperature, $\mathrm{pH} 6.5$ with an addition of $10 \mathrm{~g}$ bagasse and $50 \mathrm{~mL}$ distilled water for six days. Another study done by Rachman et al. [7] stated that the optimum penicillin production is done at $28^{\circ} \mathrm{C}$ and $\mathrm{pH} 7$ for 192 hours with $50 \%$ glucose substrate and phenylacetic acid precursor $\left(1 \mathrm{mg} \mathrm{L}^{-1}\right)$. The products showed antibacterial activities with $25 \mathrm{~mm}$ clear zones on average. This study aims to produce the active compound Pen $G$ from $P$. chrysogenum by carbon source variation and PAA precursor to optimize the culture media. The second objective is to confirm the activity and the presence of Pen G compound as a spot, compared with the standard Pen G. This research is expected to play a role in developing $P$. chrysogenum strains that produce high Pen $G$ so that it is expected to help in the supply of $\beta$-lactam antibiotic raw materials in the country.

\section{Methodology}

\subsection{Materials}

The materials used were Potato Dextro Agar (PDA) (Himedia), Nutrient Agar (NA) (Himedia), Potato Dextro Broth (PDB) (Himedia), Nutrient Broth (NB) (Himedia), (lactose, glucose, maltose, sucrose, Merck), $\left(\mathrm{Na}_{2} \mathrm{SO}_{4 \cdot 7} \cdot 7 \mathrm{H}_{2} \mathrm{O}, \quad \mathrm{KH}_{2} \mathrm{PO}_{4}, \quad\left(\mathrm{NH}_{4}\right)_{2} \mathrm{SO}_{4}, \quad \mathrm{MgSO}_{4 \cdot} \cdot 7 \mathrm{H}_{2} \mathrm{O}\right.$, $\mathrm{ZnSO}_{4} \cdot 7 \mathrm{H}_{2} \mathrm{O}$, Merck), yeast extract (Merck), and Phenylacetic Acid (PAA), (Sigma Aldrich). The instruments used in this study were shaker (Thermolyne), laminar airflow (Esco), autoclave (Tomy), microwave, HPLC (Shimadzu Prominence), and commonly used glass tools.

\subsection{Culture of $\boldsymbol{P}$. chrysogenum Isolate}

The $P$. chrysogenum from IPBCC (IPB culture collection) isolate's hyphae were taken and inoculated in the PDA medium $(3.9 \% \mathrm{~b} / \mathrm{v})$ and incubated at room temperature for 48 hours [7].

\subsection{Culture of Pathogenic Bacteria Isolates}

The pathogenic bacteria E. coli, S. typhi, S. aureus, and B. subtilis from the culture stock in the Laboratory of Applied Genetic Engineering and Protein Design, LIPI. The isolates' colonies (one pick of inoculation loop) inoculated in the NA medium $(2.8 \% \mathrm{~b} / \mathrm{v})$ and incubated at room temperature for 24 hours [17].

\subsection{Pen-G Production with Carbon Source Variation}

The suspense of $P$. chrysogenum spores grown in the standard PDB medium was transferred into the activation medium, containing $0.85 \% \mathrm{NaCl}$ and $1-2$ drops of Tween $80.2 \%(\mathrm{v} / \mathrm{v})$ of the activation medium was added into the Pen $\mathrm{G}$ production medium (Table 1). The production medium was incubated for ten days with agitation at room temperature. The addition of the Phenylacetic Acid (PAA) precursor was done three days after the bioproduction from fungi took place [7, 18].

Table 1. Pen G production medium composition with varied carbon sources in $100 \mathrm{~mL}$ culture medium

\begin{tabular}{clc}
\hline No. & \multicolumn{1}{c}{ Production medium } & $\begin{array}{c}\text { Weight } \\
(\mathrm{g})\end{array}$ \\
\hline 1 & $\mathrm{KH}_{2} \mathrm{PO}_{4}$ & 0.4 \\
2 & $\left(\mathrm{NH}_{4}\right)_{2} \mathrm{SO}_{4}$ & 0.45 \\
3 & $\mathrm{MgSO}_{4 \cdot 7 \mathrm{H}_{2} \mathrm{O}}$ & 0.05 \\
4 & $\mathrm{Na}_{2} \mathrm{SO}_{4} \cdot 7 \mathrm{H}_{2} \mathrm{O}$ & 0.15 \\
5 & $\mathrm{ZnSO}_{4} \cdot 7 \mathrm{H}_{2} \mathrm{O}$ & 0.2 \\
6 & Yeast Extract & 0.5 \\
7 & Phenylacetic Acid (PAA) & $0-0.6$ \\
8 & Carbon Source Variation (Lac, Glu, & 1.5 \\
& Suc, Mal) and PDB & \\
\hline
\end{tabular}

Notes: Lac $=$ Lactose, Glu $=$ Glucose, Suc $=$ Sucrose, Mal $=$ Maltose and $\mathrm{PDB}$ as standard medium. PAA concentration variation $(0, A, B, C, D, E, F) .0=0 \mathrm{gL}^{-1} ; A=$ $0.1 \mathrm{gL}^{-1} ; \mathrm{B}=0.2 \mathrm{gL}^{-1} ; \mathrm{C}=0.3 \mathrm{gL}^{-1} ; \mathrm{D}=0.4 \mathrm{gL}^{-1} ; \mathrm{E}=0.5 \mathrm{gL}^{-1}$; $\mathrm{F}=0.6 \mathrm{gL}^{-1}$

\subsection{Pen G Production with Various PAA Concentration}

The production media from carbon source optimization were varied with the addition of precursor (PAA). The composition of the production medium and variation of PAA concentration was employed from the previous method (Table 1). Observation of Pen G products was done by extracting $10 \mathrm{~mL}$ of supernatant after ten days of fermentation, in which after, Pen $G$ concentration and $\mathrm{pH}$ of the medium were analyzed [19].

\subsection{Analysis of Pen $\mathrm{G}$ from Bioproduction Process}

The culture sample was harvested with centrifugation at $6000 \mathrm{rpm}$ for $15 \mathrm{~min}$ at room temperature after cultivation. The resulting filtrates included including crude extract Pen G, extracellular bioproduct, without extracting the organic solution's culture sample. A stock of crude extract Pen G was filtered, sterilized $(0.25 \mu \mathrm{m})$, and stored in aliquots at$4^{\circ} \mathrm{C}$. Afterward, the Pen $\mathrm{G}$ concentration in the sample filtrates was assessed by injecting the crude extract Pen $\mathrm{G}$ into the HPLC instrument. The HPLC criteria: HPLC 
Shimadzu, detector UV $220 \mathrm{~nm}, \mathrm{C}-18$ column, with methanol: phosphate buffer $10 \mathrm{mM}(80: 20)$ as the mobile phase, at room temperature and flow rate of $1 \mathrm{~mL} / \mathrm{min}$. The standard Pen $\mathrm{G}$ used was penicillin $\mathrm{G}$ sodium salt with $1000 \mathrm{mg} \mathrm{L}^{-1}$ [20]. To obtain Pen-G concentration was used a single standard method: C1/A1 = C2/A2, each defined as $\mathrm{C} 1=$ standard concentration of Pen $\mathrm{G}(1 \mathrm{~g} / \mathrm{L})$, $\mathrm{A} 1=$ standard peak area of Pen $\mathrm{G}, \mathrm{C} 2=$ concentration of the sample, $\mathrm{A} 1=$ peak area of the sample [21].

The Pen-G's antibacterial activities from the fungi cultures were assessed by employing the disk diffusion method. The disks were put onto the NA medium previously inoculated with each $0.3 \mathrm{~mL}$ of pathogenic bacteria (S. aureus, B. subtilis, and S. typhi). $30 \mu \mathrm{L}$ of Pen$\mathrm{G}$ samples were pipetted onto each disk and incubated for 24 hours at room temperature. Subsequently, the developed clear zones were analyzed. Positive (penicillin G sodium salt) and negative (methanol) controls were included in each test. The developed clear zones showed the strength of Pen G activities [22, 23].

The presence of Pen G spots was confirmed by the Thin Layer Chromatography (TLC) method. Prior, the filtrated samples that contain Pen $\mathrm{G}$ were extracted with Chloroform solvent $(1: 1 \mathrm{v} / \mathrm{v})$. The Pen $\mathrm{G}$ extracts were then obtained by evaporating the organic solvent. The Pen G extracts were then applied to the TLC plate and eluted with ethyl acetate: distilled water: acetic acid (60:20:20) as the mobile phase. After that, the TLC was dried by heat until the spots were visible on top of the TLC plates. Prediction of the compound was carried out under UV light at $254 \mathrm{~nm}$ [24].

\subsection{Data Analysis}

All data performed were as mean \pm SD Data, analyzed using ANOVA and tested with Tukey HSD (Honestly Significant Difference) using software IBM SPSS Statistics 25.

\section{Results and Discussion}

\subsection{The Growth Medium Influence on Pen G Production}

The Initial medium to observe endophytic fungus $P$. chrysogenum presence and growth were carried out using the PDA standard medium. The observation showed that the unique fungus characteristics, green-colored in the upper part, and pale-yellow colored in the hyphae's basal part (Figure 2). Further, the penicillin metabolite's production from the fungus was done in the PDB medium and various carbon media (Table 1). As mentioned before, the analyzed Pen-G product was the crude extract (extracellular bio-product), without extracting the sample. Subsequently, the product was compared with the standard. The assignment of samples' concentration was referred as the spectrum of standard pen-G employing HPLC. Observation from the standard Pen G (Pen G sodium salt) employing C-18 column HPLC showed the presence of standard (as positive control) peak spectrum retention at 2.738 minutes (Figure 3a). The confirmation of penicillin production from the $P$. chrysogenum fungus was referred to the same retention time from the standard, 2.737 minutes (3b).

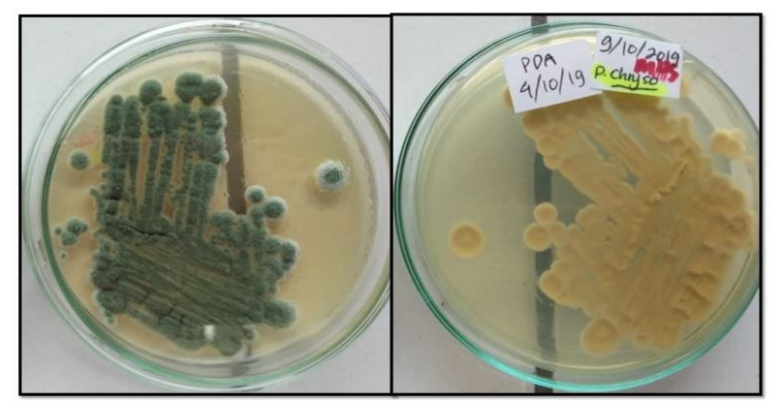

Figure 2. P. chrysogenum fungus' isolate in a PDA standard medium at room temperature.

a.
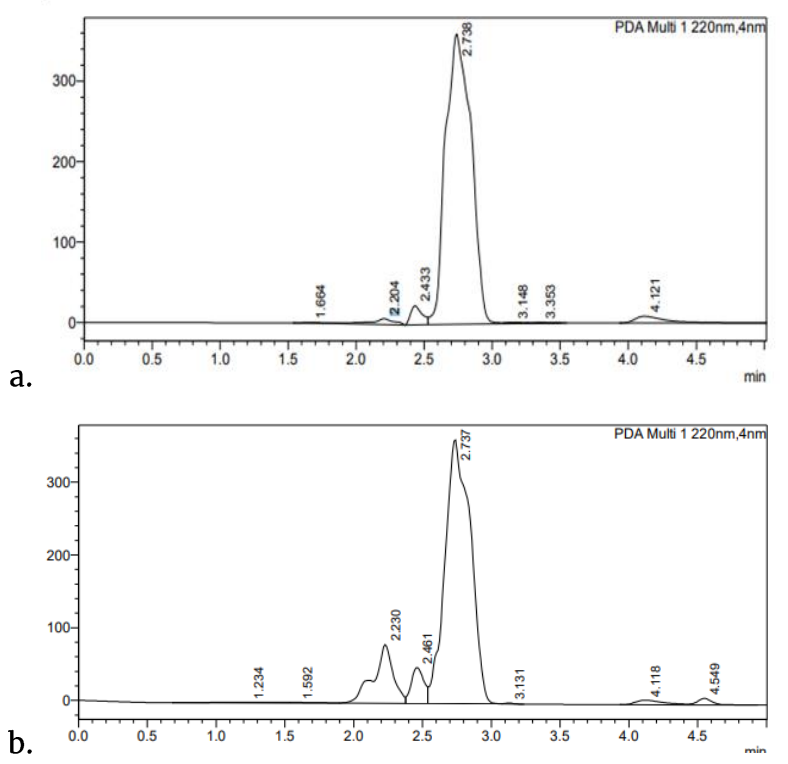

Figure 3. The standard peak of penicillin $G$ sodium salt as a positive control (a) and a peak of penicillin- $G$ from bioproduction (b).

Based on the produced Pen G metabolite's analysis and result declare as average $\pm S D \quad(n=4)$, the concentration varied from $0.107 \mathrm{gL}^{-1}$ to $0.425 \mathrm{gL}^{-1}$ as the highest concentration produced (Figure 4). Referenced from Figure 4, the highest Pen $\mathrm{G}$ metabolite produced is $0.425 \mathrm{gL}^{-1}$ from the PDB medium. That result was higher than the lactose medium, with only $0.107 \mathrm{gL}^{-1}$ of Pen $\mathrm{G}$ produced and the other carbon sources. The results showed that proper nutrition supply heavily influences the characteristics of $P$. chrysogenum. The P. chrysogenum fungus cultured in the PDB medium has a higher concentration of Pen $\mathrm{G}$ produced than the other carbon sources, viz. lactose, maltose, sucrose, and glucose. The PDB medium contains complex sugar (polysaccharide), contains nutrition intake as the complex sugar needed to be hydrolyzed first by enzymes into simple sugars [25]. The mentioned condition caused the fungus to work harder to produce the required enzymes [15]. The enzyme's mechanism caused the fungus to create other secondary products, which was the penicillin antibiotic [26].

In contrast to glucose, a simple sugar, it can be readily absorbed by the fungus [27]. The smoother the 
absorption occurs, the higher it is for primary metabolites to be produced [28]. Onyegeme-Okerenta et al. [15] reported that Pen G production from $P$. chrysogenum fungus was affected by many factors, including carbon nutrition. The carbon source used in fungus' growth can be monosaccharide (glucose, fructose, galactose), disaccharide (sucrose, lactose, maltose), and/or complex carbon like starch $[29,30]$.

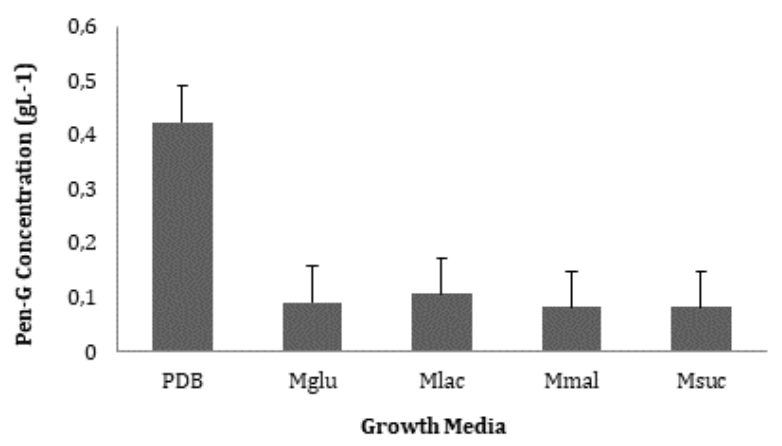

Figure 4. The Pen $\mathrm{G}$ production from $P$. chrysogenum fungus in various media (PDB: Potato Dextrose Broth, Mglu: Pen G production medium with glucose, Mlac: Pen $\mathrm{G}$ production medium with lactose, Mmal: Pen G production medium with maltose, Msuc: Pen G production medium with sucrose). This result declares as average $\pm S D(n=4)$

\subsection{Addition of Phenylacetic Acid (PAA) towards the Penicillin G Production}

Pen $G$ production from $P$. chrysogenum fungus in the production medium with PAA addition gave a significantly different result. Pen $G$ production in the PAA-added lactose medium was increased by $0.6 \mathrm{gL}^{-1}$, compared to the standard PDB medium with similar PAA concentration added (Figure 5). The tendency of Pen G concentration to increase is linearly attributed to the rise of PAA concentration in the lactose culture medium. A decreasing trend occurred at $0.3 \mathrm{gL}^{-1}$ addition of PAA, although the trend recovered in the next higher concentration. This phenomenon can be caused by the medium's unstable $\mathrm{pH}$, which led to cells' autolysis. The increasing trend of Pen $\mathrm{G}$ in the lactose medium with 0.6 $\mathrm{gL}^{-1}$ PAA addition achieved the optimal concentration around $2.460 \mathrm{gL}^{-1}$ until the final concentration of 2.565 $\mathrm{gL}^{-1}$, whilst in the PDB medium, the highest Pen G produced is $0.470 \mathrm{gL}^{-1}$. The use of precursors is significant for Pen $G$ production [31]. PAA is a precursor and the central of Pen G metabolism [32]. If PAA is supplied into the fermentation media of $P$. chrysogenum, the Pen $\mathrm{G}$ would be secreted into the medium [33].

In industries of Pen $\mathrm{G}$ production, the addition of precursor is needed. With the precursor, the higher the chances for microbes to produce various types of penicillin depending on available precursor, e.g., penicillin $\mathrm{F}$ and $\mathrm{K}$, which contain 3-hexanoic acid and octanoic acid. Phenoxy acetic acid is the precursor of phenoxymethylpenicillin (penicillin V), while PAA acts as the hydrophobic side chain of benzylpenicillin or Pen $G$ [34]. On average, the Pen $G$ produced with varied carbon sources has a far lower concentration than in the media with PAA addition. PAA precursors can support the optimum Pen $G$ production if given proper doses [35]. However, PAA can be contra-productive for the growth and production of fungus because of its acidic property. This acidic property is toxic to the fungus culture [36]. Pen G production can decrease in high PAA concentration because of the increased rate of cells' autolysis. Insufficient PAA concentration can also decrease Pen $G$ produced, although it has insignificant effects on the cells' autolysis [37].

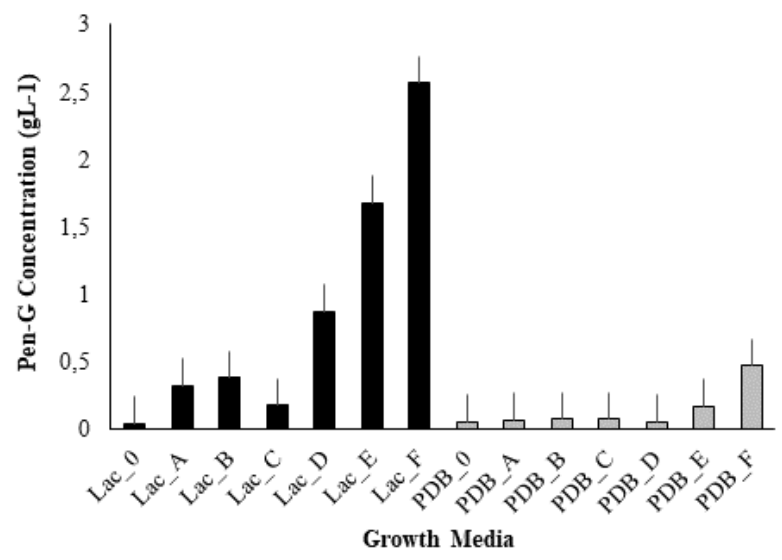

Figure 5. The Pen G production from P. chrysogenum fungus with the various concentration of phenylacetic acid (PAA) precursor in Pen $\mathrm{G}$ production contain lactose (Lac) and Potato Dextrose Broth (PDB) medium. Vertical bars show the standard error of the mean based on four independent measurements. Each block of difference color shows the real difference at the $(\mathrm{P}<0.05)$ level, based on the Tukey HSD test.

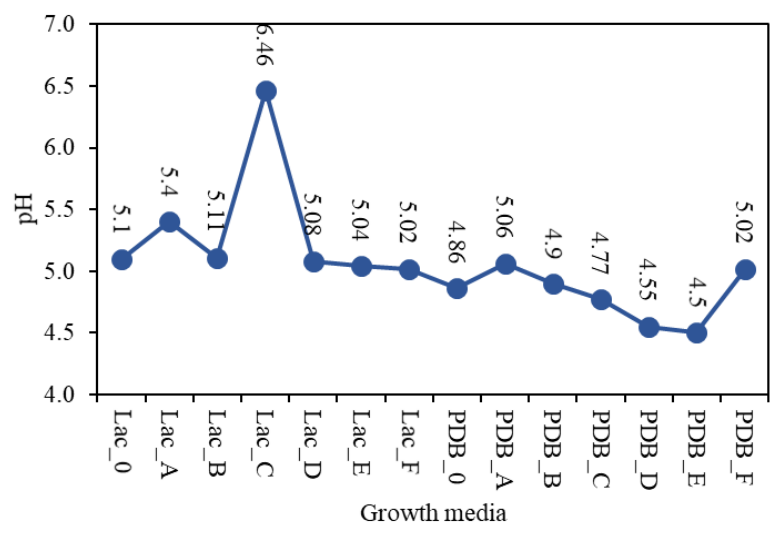

Figure 6. Graphic of final fermentation $\mathrm{pH}$ from $P$. chrysogenum fungus with the various concentration of phenylacetic acid (PAA) precursor in Pen G production contain lactose (Lac) and Potato Dextrose Broth (PDB)

medium. This result declares as average $\pm n=2$.

Based on the study done by Wagner et al. [38], PAA concentration below $0.25 \mathrm{gL}^{-1}$ could cause an unstable condition in the reactor, whereas PAA concentration above $0.5 \mathrm{gL}^{-1}$ could inhibit the fungus' growth. Other than that, referenced from [37], PAA's addition above 1 $\mathrm{gL}^{-1}$ could inhibit penicillin's biosynthesize. The $\mathrm{pH}$ of the fermented filtrates in both lactose and PDB medium were analyzed at room temperature. The filtrate from the lactose medium was known to have a stable $\mathrm{pH}$ in the range of 4.5 , while filtrate from the PDB medium is in the range of $\mathrm{pH} 5.4$ (Figure 6). The different condition 
was shown from the lactose medium with $0.3 \mathrm{gL}^{-1} \mathrm{PAA}$ addition, in which the $\mathrm{pH}$ was increased up to $\mathrm{pH} 6.46$. This extreme $\mathrm{pH}$ escalation caused the stability of $P$. chrysogenum growth to be disturbed, furthered with a decreasing trend of pen- $\mathrm{G}$ concentration in the filtrate. In the previous study, $\mathrm{pH}$ above 6.0 caused the fungus' growth to be unstable, subsequently affecting the Pen $\mathrm{G}$ production (decreasing). In contrast, the culture's $\mathrm{pH}$ below 4.0 disturbed P. chrysogenum growth [39].

\subsection{Analysis of Penicillin G Bioproduction}

The antibacterial activities assessment from the potential strain of $P$. chrysogenum for Pen G production was done employing the disk diffusion method. The bioactivity of Pen $\mathrm{G}$ was shown to be potent against both the Gram-positive (S. aureus and B. subtilis) and negative (S. typhi) bacteria (Table 2). The inhibition zone from the samples actively inhibits the tested pathogenic bacteria, shown by the presence of clear zones, compared to the positive control (penicillin $1000 \mathrm{mg} \mathrm{L}^{-1}$ ).

Table 2. Inhibition zone of Pen-G filtrated samples against tested bacteria; S. aureus, S. typhi, and B. subtilis

\begin{tabular}{|c|c|c|c|c|}
\hline \multirow[t]{2}{*}{ No. } & \multirow[t]{2}{*}{ Filtrate sample } & \multicolumn{3}{|c|}{$\begin{array}{l}\text { Zone of inhibition against tested } \\
\text { bacteria }(\mathrm{mm})\end{array}$} \\
\hline & & S. aureus & S. typhi & B. subtilis \\
\hline 1 & Lac_o & 9 & 7.5 & 6.5 \\
\hline 2 & Lac_A & 8.5 & 11 & 10 \\
\hline 3 & Lac_B & 13 & 10 & 11 \\
\hline 4 & Lac_C & 12 & 9 & 12 \\
\hline 5 & Lac_D & 8 & 11 & 11.5 \\
\hline 6 & Lac_E & 8.5 & 8 & 12 \\
\hline 7 & Lac_F & 15 & 11 & 15 \\
\hline 8 & $+\underset{1}{+})\left(1 \mathrm{~g} \mathrm{~L}^{-}\right.$ & 15 & 8.5 & 13 \\
\hline 9 & $\begin{array}{l}\text { - control } \\
\text { (chloroform) }\end{array}$ & 0 & 0 & 0 \\
\hline 9 & PDB_0 & 7 & 8.5 & 9 \\
\hline 10 & PDB_A & 8.5 & 7 & 11 \\
\hline 11 & PDB_B & 12.5 & 7 & 10 \\
\hline 12 & PDB_C & 11 & 8.5 & 8 \\
\hline 13 & PDB_D & 7 & 7 & 9 \\
\hline 14 & PDB_E & 6.5 & 7 & 9 \\
\hline 15 & PDB_F & 11 & 8 & 9 \\
\hline
\end{tabular}

Notes: Lac $=$ Lactose, Glu= Glucose, Suc $=$ Sucrose, Mal= Maltose and PDB as standard medium. PAA Concentration Variation ( $0, \mathrm{~A}, \mathrm{~B}, \mathrm{C}, \mathrm{D}, \mathrm{E}, \mathrm{F}) .0=0 \mathrm{gL}^{-1} ; \mathrm{A}=$ $0.1 \mathrm{gL}^{-1} ; \mathrm{B}=0.2 \mathrm{gL}^{-1} ; \mathrm{C}=0.3 \mathrm{gL}^{-1} ; \mathrm{D}=0.4 \mathrm{gL}^{-1} ; \mathrm{E}=0.5 \mathrm{gL}^{-1}$; $\mathrm{F}=0.6 \mathrm{gL}^{-1}$

In the beginning, Pen G was known only effectively to inhibit Gram-positive bacteria [40]. Therefore, a derivative of penicillin has been developed, which has a broader spectrum of Gram-positive and Gram-negative bacteria, one of which is amoxicillin. However, after updated studies, Pen G was shown to have the ability against Gram-negative bacteria such as $S$. typhi. This phenomenon may be caused by the nutrition source combined with the production medium of Pen G. The application of semi-synthetic material conjoined with enzymatic reactions can shift Pen G production into different targets [11].

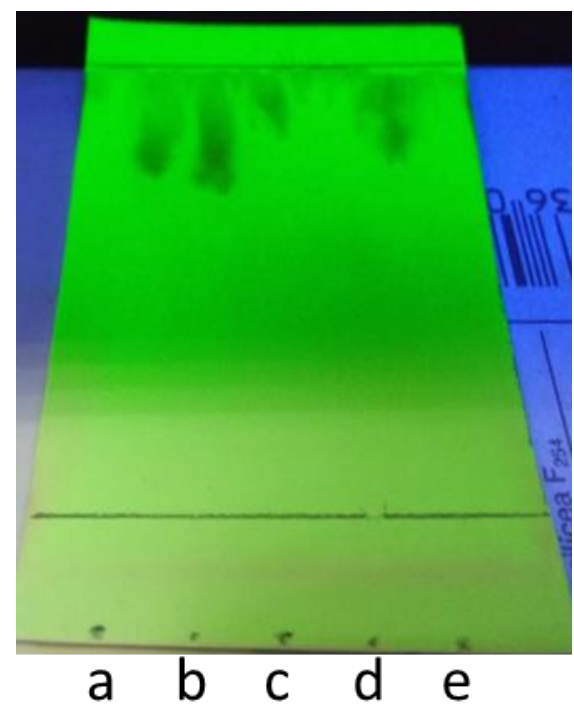

Figure 7. Spots from Pen G elution in ethyl acetate: distilled water: acetic acid (60: 20: 20); (a) Pen G standard (1 $\left.\mathrm{gL}^{-1}\right)$; (b)-(c) spots from lactose media; (d)(e) spots from PDB media in UV $254 \mathrm{~nm}$

Identification of potential Pen G spots on the ethyl acetate: distilled water: acetic acid (60:20:20) mobile phase was done with the Thin Layer Chromatography method (Figure 7). Pen G spots can be seen under the UV light after dried by heat and does not require any markers. Prediction of the compound was identified under $254 \mathrm{~nm}$ UV light. The TLC method usage was to see the presence of Pen-G spots in extracts after being separated with appropriate organic solvents. Afterward, the spots can be migrated and identified. The similarity between the observed standard-derived and samplederived Pen $\mathrm{G}$ spots showed the presence of spots at Rf $0.65 \mathrm{~cm}$.

\section{Conclusion}

This study confirmed that proper nutrition and PAA precursor addition could increase the Pen G bioproduction from $P$. chrysogenum fungus. The addition of $0.6 \mathrm{gL}^{-1} \mathrm{PAA}$ in the lactose sourced medium increased the production of Pen $\mathrm{G}$ up to $2.46 \mathrm{gL}^{-1}$.

\section{Acknowledgment}

The authors would like to thank the Indonesian Institute of Sciences for the funding support through DIPA Health and Drugs 2019 and the Laboratory of Applied Genetic Engineering and Protein Design at LIPI Cibinong for this experiment. We also wish to thank IPBCC for permission to use the fungi isolate.

\section{Contribution}

The authors declare that Martha Sari and Dirayanti (main contributors), Eris Septiana, Bustanussalam, and Zainal Apon (other contributors), are responsible for all activities, including the concept development, design, laboratory, and data analysis, writing, as well as revisions its publication. 


\section{References}

[1] Hong Lu, Wen Xin Zou, Jun Cai Meng, Jun Hu, Ren Xiang Tan, New bioactive metabolites produced by Colletotrichum sp., an endophytic fungus in Artemisia annua, Plant Science, 151, 1, (2000), 67-73 https://doi.org/10.1016/S0168-9452(99)00199-5

[2] Sana Fatima, Akhtar Rasool, Nasreena Sajjad, Eijaz Ahmed Bhat, Marlia Mohd Hanafiah, Mohammed Mahboob, Analysis and evaluation of penicillin production by using soil fungi, Biocatalysis and Agricultural Biotechnology, 21, (2019), 101330 https://doi.org/10.1016/j.bcab.2019.101330

[3] Stephen Goldrick, Barry Lennox, David Lovett, Keith Smith, Gary Montague, The Development of a Simulation to Address the Real Challenges Associated with Industrial Scale Penicillin Production, IFAC Proceedings Volumes, 46, 31, (2013), 24-29

https://doi.org/10.3182/20131216-3-IN-2044.00069

[4] Daniele Canzani, Fadi Aldeek, Penicillin G's function, metabolites, allergy, and resistance, Journal of Nutrition and Human Health, 1, 1, (2017), 2840

https://doi.org/10.35841/nutrition-humanhealth.1.1.28-40

[5] Sietske Grijseels, Jens Christian Nielsen, Jens Nielsen, Thomas Ostenfeld Larsen, Jens Christian Frisvad, Kristian Fog Nielsen, Rasmus John Normand Frandsen, Mhairi Workman, Physiological characterization of secondary metabolite producing Penicillium cell factories, Fungal Biology and Biotechnology, $\quad 4, \quad 1, \quad$ (2017), 8 https://doi.org/10.1186/s40694-017-0036-z

[6] Carlos Barreiro, Juan F. Martín, Carlos GarcíaEstrada, Proteomics Shows New Faces for the Old Penicillin Producer Penicillium chrysogenum, Journal of Biomedicine and Biotechnology, 2012, (2012), 105109 https://doi.org/10.1155/2012/105109

[7] Saadah D. Rachman, Agus Safari, Fazli Fazl, Dian S. Kamara, Abubakar Sidik, Linar Z. Udin, Safri Ishmayana, Produksi Penisilin oleh Penicillium chrysogenum L112 dengan Variasi Kecepatan Agitasi pada Fermentor 1 L, Kartika: Jurnal Ilmiah Farmasi, 4, $2,(2016), 1-6$ http://dx.doi.org/10.26874/kjif.v4i2.59

[8] Loknath Gidijala, Jan A. K. W. Kiel, Rutger D. Douma, Reza M. Seifar, Walter M. Van Gulik, Roel A. L. Bovenberg, Marten Veenhuis, Ida J. Van Der Klei, An engineered yeast efficiently secreting penicillin, PLoS One, 4, 12, (2009), e8317 https://doi.org/10.1371/journal.pone.0008317

[9] Fernando Guzmán-Chávez, Reto D. Zwahlen, Roel A. L. Bovenberg, Arnold J. M. Driessen, Engineering of the Filamentous Fungus Penicillium chrysogenum as Cell Factory for Natural Products, Frontiers in Microbiology, 9, 2768, (2018), 1-25 https://doi.org/10.3389/fmicb.2018.02768

[10]Mariya Lobanovska, Giulia Pilla, Penicillin's discovery and antibiotic resistance: lessons for the future?, The Yale journal of biology and medicine, 90, 1, (2017), 135-145

[11] Ivan Pradipta, Elis Ronasih, Arrum Kartikawati, Hartanto Hartanto, Rizki Amelia, Ellin Febrina, Rizky Abdulah, Three years of antibacterial consumption in Indonesian Community Health
Centers: The application of anatomical therapeutic chemical/defined daily doses and drug utilization $90 \%$ method to monitor antibacterial use, Journal of Family and Community Medicine, 22, 2, (2015), 101-105 https://doi.org/10.4103/2230-8229.155385

[12] Mohamed Hassan, Production, Immobilization and Industrial Uses of Penicillin G Acylase, International Journal of Current Research and Review, 8, 15, (2016), 11-22

[13] Sandra Ziemons, Katerina Koutsantas, Kordula Becker, Tim Dahlmann, Ulrich Kück, Penicillin production in industrial strain Penicillium chrysogenum P2niaD18 is not dependent on the copy number of biosynthesis genes, BMC Biotechnology, $17,1,(2017), 16$ https://doi.org/10.1186/s12896-017-0335-8

[14]Maryam Asnaashari, Mohammad Ali Tajick Ghanbary, Zahra Tazick, Optimization of penicillin G production by Penicillium chrysogenum, Annals of Biological Research, 3, 12, (2012), 5434-5440

[15] B. M. Onyegeme-Okerenta, V. I. Okochi, S. N. Chinedu, Penicillin Production by Penicillium chrysogenum PCL 501: Effect of UV Induced Mutation, The Internet Journal of Microbiology, 12, 1, (2013), 1629

[16] Ioannis Ketikidis, Christina N. Banti, Nikolaos Kourkoumelis, Constantinos G. Tsiafoulis, Christina Papachristodoulou, Angelos G. Kalampounias, Sotiris K. Hadjikakou, Conjugation of Penicillin-G with Silver(I) Ions Expands Its Antimicrobial Activity against Gram Negative Bacteria, Antibiotics, 9, 1, (2020), 25 https://doi.org/10.3390/antibiotics9010025

[17] Refdinal Nawfa, Adi Purnomo, Herdayanto Putro, Synthesis of Antibiotic Penicillin-G Enzymatically by Penicillium chrysogenum, Asian Journal of Chemistry, 31, 10, (2019), 2367-2369 https://doi.org/10.14233/ajchem.2019.21766

[18] Diana M. Harris, Zita A. van der Krogt, Paul Klaassen, Leonie M. Raamsdonk, Susanne Hage, Marco A. van den Berg, Roel A. L. Bovenberg, Jack T. Pronk, Jean-Marc Daran, Exploring and dissecting genome-wide gene expression responses of Penicillium chrysogenum to phenylacetic acid consumption and penicillin $\mathrm{G}$ production, $B M C$ Genomics, 10, 1, (2009), 75 https://doi.org/10.1186/1471-2164-10-75

[19]J. Madhusudhanan, B. Bamarukmani, Optimization of phenyl acetic acid concentration during the growth phase of Penicillin-G production in pilot plant, Research Journal of Pharmaceutical, Biological and Chemical Sciences, 8, 3S, (2017), 291-301

[20]Marya Lieberman, HPLC Methodology Manual: Distributed Pharmaceutical Analysis Laboratory (DPAL), Department of Chemistry and Biochemistry, University of Notre Dame, Notre Dame, 2018

[21] Dwiarso Rubiyanto, Metode Kromatografi: Prinsip Dasar, Praktikum dan Pendekatan Pembelajaran Kromatografi, Deepublish, Yogyakarta, 2017

[22]Yulistia Budianti Soemarie, Fitri Handayani, Edna Nur Annisa, Uji Aktivitas Antibakteri Ekstrak Etanol Daun Selutui Puka (Tabernaemontana macrocarpa Jack) terhadap Bakteri Staphylococcus aureus, Jurnal Ilmiah Ibnu Sina, 3, 2, (2018), 266-274 
[23]Melzi Octaviani, Haiyul Fadhli, Erenda Yuneistya, Uji Aktivitas Antimikroba Ekstrak Etanol Kulit Bawang Merah (Allium cepa L.) dengan Metode Difusi Cakram, Pharmaceutical Sciences \& Research, 6, 1, (2019), 62-68 https://doi.org/10.7454/psr.v6i1.4333

[24]Gabriel Hancu, Brigitta Simon, Hajnal Kelemen, Aura Rusu, Eleonora Mircia, Árpád Gyéresi, Thin layer chromatographic analysis of Beta-lactam antibiotics, Advanced pharmaceutical bulletin, 3, 2, (2013), 367-371

http://dx.doi.org/10.5681/apb.2013.059

[25]Tomoya Shintani, Food Industrial Production of Monosaccharides Using Microbial, Enzymatic, and Chemical Methods, Fermentation, 5, 2, (2019), 47 https://doi.org/10.3390/fermentation5020047

[26]Ana I. Coelho, Gerard T. Berry, M. Estela RubioGozalbo, Galactose metabolism and health, Current Opinion in Clinical Nutrition \& Metabolic Care, 18, 4, (2015), 422-427 https://doi.org/10.1097/MC0.0000000000000189

[27]Madina Kechkar, Walaa Sayed, Audrey Cabrol, Majda Aziza, T. Ahmed Zaid, Abdeltif Amrane, Hayet Djelal, Isolation and Identification of Yeast Strains From Sugarcane Molasses, Dates and Figs for Ethanol Production Under Conditions Simulating Algal Hydrolysate, Brazilian Journal of Chemical Engineering, 36, 1, (2019), 157-169 https://doi.org/10.1590/01046632.20190361s20180114

[28]Eris Septiana, Partomuan Simanjuntak, Effect of Different Culture Condition on Antioxidant Secondary Metabolites from Endophytic Fungi Isolated from Turmeric Root, Majalah Obat Tradisional (Traditional Medicine Journal), 22, 1, (2017), 31-36

https://doi.org/10.22146/tradmedj.24308

[29]Ivonne Gutierréz-Rojas, Geraldine TibasosaRodríguez, Nubia Moreno-Sarmiento, María Ximena Rodríguez-Bocanegra, Dolly Montoya, Carbon and nitrogen sources differently influence Penicillium sp. HC1 conidiation in solid and liquid culture, African Journal of Microbiology Research, 9, 47, (2015), 2290-2299 https://doi.org/10.5897/AJMR2015.7779

[30]Manoshi Bhattacharya, A history of evolution of the terms of carbohydrates coining the term 'glucogenic carbohydrates' and prescribing in grams per day for better nutrition communication, Journal of Public Health and Nutrition, 1, 4, (2018), 93-100

[31] Jakub Fehér, Ivan Červeňanský, Lukáš Václavík, Jozef Markoš, Electrodialysis applied for phenylacetic acid separation from organic impurities: Increasing the recovery, Separation and Purification Technology, 235, (2020), 116222 https://doi.org/10.1016/j.seppur.2019.116222

[32]Terence S. Crofts, Bin Wang, Aaron Spivak, Tara A. Gianoulis, Kevin J. Forsberg, Molly K. Gibson, Lauren A. Johnsky, Stacey M. Broomall, C. Nicole Rosenzweig, Evan W. Skowronski, Henry S. Gibbons, Morten O. A. Sommer, Gautam Dantas, Shared strategies for $\beta$-lactam catabolism in the soil microbiome, Nature Chemical Biology, 14, 6, (2018), 556-564 https://doi.org/10.1038/s41589-018-0052-1

[33]Rutger D. Douma, Amit T. Deshmukh, Lodewijk P. de Jonge, Bouke W. de Jong, Reza M. Seifar, Joseph J. Heijnen, Walter M. van Gulik, Novel insights in transport mechanisms and kinetics of phenylacetic acid and penicillin-G in Penicillium chrysogenum, Biotechnology Progress, 28, 2, (2012), 337-348 https://doi.org/10.1002/btpr.1503

[34]Murray Moo-Young, Comprehensive Biotechnology, Elsevier Science, 2011

[35]Oleksandr Salo, Secondary Metabolism by Industrially Improved Penicillium chrysogenum Strains, University of Groningen, Gronigen, Netherland, 2016

[36]Mohammad-Saeid Jami, Juan-Francisco Martín, Carlos Barreiro, Rebeca Domínguez-Santos, MaríaFernanda Vasco-Cárdenas, María Pascual, Carlos García-Estrada, Catabolism of phenylacetic acid in Penicillium rubens. Proteome-wide analysis in response to the benzylpenicillin side chain precursor, Journal of Proteomics, 187, (2018), 243-259 https://doi.org/10.1016/j.jprot.2018.08.006

[37]Amila Pramisandi, Rofiq Sunaryanto, Suyanto, Erwahyuni Endang Prabandari, Effect of Phenylacetic Acid Addition on Productivity of Penicillium chrysogenum in Penicillin G Production Using Pilot Scale Reactor, Proceeding of International Conference on Chemical and Material Engineering, Semarang, 2012

[38]Andreas Otto Wagner, Eva Maria Prem, Rudolf Markt, Rüdiger Kaufmann, Paul Illmer, Formation of phenylacetic acid and phenylpropionic acid under different overload conditions during mesophilic and thermophilic anaerobic digestion, Biotechnology for Biofuels, 12, 1, (2019), 26 https://doi.org/10.1186/s13068-019-1370-6

[39]Ghania Bourzama, Nadjet Ennaghra, Boudjma Soumati, Saliha Benoune, Nesrine Atriche, Effect of Zinc Metal at High Concentration on Secondary Metabolic Pathways in Penicillium chrysogenum Strain, Journal of Microbiology, Biotechnology and Food Sciences, 9, 2, (2019), 307-313

https://doi.org/10.15414/jmbfs.2019.9.2.307-313

[40] Wan Zuraida Wan Mohd Zain, Jamaluddin Kassim, Shaikh Abdul Karim, Antimicrobial activity of plant extracts against Bacillus subtilis, Staphylococcus aureus and Escherichia coli, e-Journal of Chemistry, 8, S1, (2011), S282-S284 